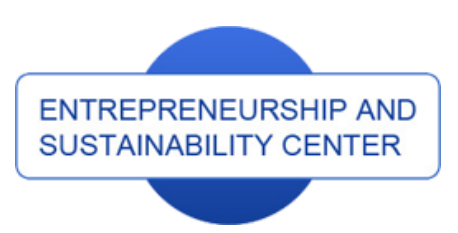

Publisher

http://jssidoi.org/esc/home

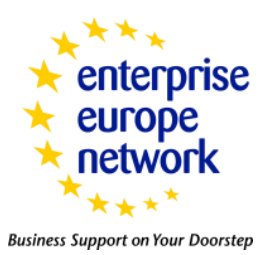

CASPA

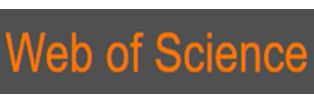

Clarivate

Analytics

\title{
SUSTAINABLE REGIONAL DEVELOPMENT POLICY FORMATION: ROLE OF INDUSTRIAL ECOLOGY AND LOGISTICS
}

\author{
Yevhen, Mishenin ${ }^{1}$, Inna, Koblianska ${ }^{2}$, Viktoriia, Medvid ${ }^{3}$, Yuliia, Maistrenko ${ }^{4}$ \\ ${ }^{1}$ Sumy State University, 2, Rymskogo-Korsakova st., 40007, Sumy, Ukraine; \\ ${ }^{2,3}$ Sumy National Agrarian University, 160, Herasym Kondratiev st., 40021, Sumy, Ukraine \\ ${ }^{4}$ Kiev University for Market Relations, 26-B, Bereznyakivskaya street, 02152, Kyiv, Ukraine
}

E-mails.1 eugeniy_mishenin@yahoo.com; ${ }^{2}$ koblyanska2@gmail.com; ${ }^{3}$ viktoriya.medved.snau@gmail.com; ${ }^{4}$ Leluka@ukr.net

Received 9 April 2018; accepted 6 July 2018; published 30 September 2018

\begin{abstract}
The impossibility to define the clear and uniform operational guidelines for the implementation of sustainable development policy globally proves the necessity to consider the regional level as the key in terms of developing and implementing modern models of sustainable development, in particular, eco-industrial parks and circular economy projects. It substantiates the need to develop and use the modern innovative methodological approaches to the formation of the relevant regional policy. The circular economy proceeds from the flow-based understanding of the character of the production, distribution, exchange, and consumption of goods in the socio-economic system and, consequently, the turnover of resources and energy within this system. It determines the need for complex analysis and regulation of material and energy flows. These issues constitute the scope of research of industrial ecology and, at the same time, logistics. This causes the question of the integration of these disciplines within the system of scientific and methodological support of the processes of formation and implementation of the policy of sustainable region's development that is as yet little investigated. The article studies the theoretical and methodological foundations of the industrial ecology and logistics, such as objects, goals, methodological principles and approaches, methods, organizational forms, etc. On this basis the ontological unity of these disciplines is brought to light: they simultaneously study the different, mutually reinforcing aspects of the industrial system's performance through the accentuation of the flow form of the organization of the movement of resources, information, and energy as an object of regulation in such system. The integration of the "environmental" vision of material flows of the regional system, as is characteristic of the industrial ecology, with their "economic" content, which characterizes the structure of the regional economic system and constitutes the object of the logistics studies, should be considered as the basis for the formation and implementation of the policy aimed to achieve the region's sustainable development goals.
\end{abstract}

Keywords: management of flows; flow thinking; industrial ecology; logistics, region's sustainable development; circular economy; regional policy

Reference to this paper should be made as follows: Mishenin, Y.; Koblianska, I.; Medvid, V.; Maistrenko, Y. 2018. Sustainable regional development policy formation: role of industrial ecology and logistics, Enterpreneurship and Sustainability Issues 6(1): 329-341. http://doi.org/10.9770/jesi.2018.6.1(20)

JEL Classifications: Q01, B41, Q57, R58 
The International Journal

ENTREPRENEURSHIP AND SUSTAINABILITY ISSUES

ISSN 2345-0282 (online) http://jssidoi.org/jesi/

2018 Volume 6 Number 1 (September)

http://doi.org/10.9770/jesi.2018.6.1(20)

\section{Introduction}

The achievement of the sustainable development, which remains more of a political argument (Kronenberg 2006, p.100), requires the introduction of practical models and mechanisms for the development of business, regions, and countries in a sustainable manner. The impossibility to define the clear and uniform operational guidelines for the implementation of sustainable development policy globally proves the necessity to consider the regional level as the key in terms of developing and implementing modern models of sustainable development, in particular, eco-industrial parks and circular economy projects (Korhonen et al. 2018). On this level, it is ensured the effective implementation of the institutional power to solve a specific, local complex of socio-ecological and economic problems of the territory. In this context, the main focus should be given to the development and use of the modern innovative methodological approaches to the formation of the relevant regional policy.

The circular economy seen as a form of interorganizational, environmentally sustainable management (Korhonen et al. 2018) is based on the flow-based understanding of the character of the production, distribution, exchange, and consumption of goods in the socio-economic system and, consequently, of the turnover of resources and energy within this system (Mishenin \& Koblianska 2017). From this perspective, the need for the complex study of the material and energy flows in an industrial system becomes apparent. This determines the importance of the use of the concept of industrial ecology as a methodological basis for the formulation and implementation of policies aimed to achieve the environmental goals of such systems functioning (Hond 2000; Korhonen et al. 2018; Seuring 2004). On the other hand, the content and character of the relationships of economic agents, integrated into a single flow of consumer value creation, are disclosed through the study of material and energy flows within the framework of the logistics methodology. The latter aims to ensure the optimal composition and structure of flows in terms of system-wide (full) costs (or profit). The unity of the flow-based essence of these scientific disciplines raises the question about the possibility of their integration within the system of scientific and methodological support of the processes of formation and implementation of the policy of sustainable region's development that is as yet little investigated.

As it follows from results of the latest scientific research in this field, the forms of logistic organization and corresponding models of logistic management, in particular, environmental (Seuring 2004), ecological and ecologically sustainable (Kan 2007; Leigh \& Li 2015; Wichaisri \& Sopadang 2017), green (Sarkis 2012; Zhu et al. 2008), closed-loop (Hernández-Hernández \& Montoya Torres, 2011) supply chains are seen as one of the forms as well as the prerequisite for the implementation of the industrial ecology principles, indicating the interconnection of these disciplines. The participants within these chains are tied by the material and energy flows formed along the product life cycle (Kan 2007; Seuring 2004). These flows, as well as relationships between participants and their decisions concerning these flows, constitute the scope of industrial ecology studies. Industrial ecology focuses on a cohesive vision of physical flows of materials and energy to reduce environmental impacts within the industrial system, and therefore, commercial aspects and business relationships are not considered as the key issues (Kovács 2017). The main focus is on the assessment of the environmental aspects of flows that serves as a basis for governance and policy-making through green industries innovations (Korhonen 2002; Melnyk \& Kubatko 2013). At the same time, the methodological principles of logistics based on the systemic study of flow processes provide the understanding of the formation and development of such integrated structures in terms of economics (Kan 2007; Møller 1995; Seuring 2004). While the assessment of the total costs related with flows in networks and economic valuation of environmental goods and services is seen as a driver for the development of eco-industrial parks (Dea \& Freeman 1995; Melnyk \& Kubatko 2012) as well as an important factor of the development of green supply chains (Sarkis 2012; Seuring, 2004) and models of industrial symbiosis (Chertow \& Ehrenfeld 2012), the logistic design should be considered as a tool for systematic planning and implementation of industrial ecology models, ensuring their effective functioning both in terms of environmental impact and costs (Dea \& Freeman 1995, p. 85). However, this issue has not been explored enough. The lack of 
The International Journal

ENTREPRENEURSHIP AND SUSTAINABILITY ISSUES

ISSN 2345-0282 (online) http://jssidoi.org/jesi/

2018 Volume 6 Number 1 (September)

http://doi.org/10.9770/jesi.2018.6.1(20)

scientific investigation stipulates the expediency and necessity of a more detailed, thorough and joint study of the methodological principles of industrial ecology and logistics in order to determine the possibilities of their integration as the basis for the formation of the effective and efficient policy of sustainable development of the region that constitutes the goal of this study.

\section{The industrial ecology foundations}

In its essence, the industrial ecology implies the metaphorical transfer of ecosystem's functioning vision into the sphere of industrial development. From the standpoint of industrial ecology, the industrial system appears as an ecosystem, where companies are viewed as organisms, and which is seen as an integral part of the natural system (Ashton 2009). Accordingly, the principles of functioning and development of the industrial system are formulated based on the simulation of natural patterns: the establishment of the sufficient and cyclical models of resources and energy use, the support of diversified forms of economic agents as well as the simulation of the natural ways of intercommunication (symbiosis through the cooperation) (Kronenberg 2006). The consideration of an economic system as a part of the natural (Constanza et al. 1991) highlights the issues of regulating the metabolism of the economic system (industrial metabolism), i.e., the flows of the substance, energy and information circulating in the sphere of production and consumption as well as between the economic and the natural systems and regarded as a part of natural material-energy cycles (Baccini \& Brunner 2012; Korhonen 2002). The systemic analysis and regulation of these flows constitute the methodological basis for the research in the field of the industrial ecology (Hond 2000; Korhonen 2002; Schiller et al. 2014). The paper by Sineviciene et al. 2017 states that institutional factors, e.g. EU accession and common European energy policy are important factors that stimulate energy efficiency improvements. One should emphasize the difficulty of a distinct identification of the content (parts) of these flows, which is determined by the time, spatial and cultural attributes (Korhonen et al. 2018).

The main objective of the industrial ecology is to reduce the environmental impact associated with the functioning of the industrial system. This presupposes the optimization of the utilization of materials and energy through the minimization of waste in cascading and cyclic models of resources use (e.g. wastes and by-products), the elimination (or at least the minimization) of the toxic substances implication as well as the priority of the applying of natural materials and natural ecosystems functions (Hond 2000; Korhonen 2002; Kronenberg 2006). It should be emphasized that from the standpoint of industrial ecology economic goals appear as secondary, to some extent consequential, additional results (Korhonen 2002; Kovács 2017). This is the main argument for the critique of industrial ecologists (Desroches 2002; Kronenberg 2006).

In addressing the objectives of the industrial ecology, special attention is paid to the life cycle analysis (LCA) (Hond 2000; Korhonen 2002; Seuring 2004). This tool, being used to assess the full environmental impact formed within the product movement system (design-production-distribution consumption-utilization), creates the space of alternatives concerning cooperation of various participants within the industrial system. The substance/material flows analysis are the other important approaches used to evaluate the "environmental price" of current production models (Baccini \& Brunner 2012; Sarkis 2012).

A distinctive feature of the industrial ecology is a fundamental paradigm shift that centers around the understanding of the interconnection of industrial processes, and hence, the necessity to consider the industrialenvironmental relations in order to reduce the negative environmental impact of the system in a whole (Boons \& Baas 1997; Hond 2000). Thus, the focus should be paid not to the individual production processes, i.e. sources of pollution where the strategy of prevention and control is applied, but to the interprocess and inter-organizational (inter-firm) interactions (Hond 2000; Walls \& Paquin 2015). Therefore, the problem of coordination of actors and 


\section{The International Journal}

ENTREPRENEURSHIP AND SUSTAINABILITY ISSUES

ISSN 2345-0282 (online) http://jssidoi.org/jesi/

2018 Volume 6 Number 1 (September)

http://doi.org/10.9770/jesi.2018.6.1(20)

their activities (processes) is one of the central problems in the industrial ecology concept implementation (Boons \& Baas 1997, p. 79).

The region is an "ideal way" of the implementation of the philosophy of industrial ecology (Korhonen 2002, p. 49), as the classic examples in Calundborg and Styria province show (Desroches 2002; Ehrenfeld \& Gertler 1997; Ehrenfeld 2000). Although in the regional system different actors are not directly interconnected in their key activities (Baas \& Boons 2004; Korhonen 2002), the physical proximity is an important factor of the development of cooperation for the use of material and energy resources (waste and by-products) (Baas \& Boons 2004; Hond 2000; Korhonen 2002; Korhonen et al. 2018; Kronenberg 2006), i.e. the "industrial symbiosis" models, where the distinctive feature is the formation of a system-wide environmental result as a consequence of the interactions of the economic agents (Chertow \& Ehrenfeld 2012). Such a regional system, which operates as an eco-industrial park (EIP), can be relatively easily controlled and managed from the point of view of the involved actors. The presence of government coordinating institutions is an important factor in its development (Baas \& Boons 2004; Boons \& Baas 1997; Chertow \& Ehrenfeld 2012; Walls \& Paquin 2015).

An important problem of the practical implementation of the industrial ecology principles is the role of government institutions in this process. This may include, in particular (Baas \& Boons 2004; Chertow \& Ehrenfeld 2012; Desroches 2002; Ehrenfeld \& Gertler 1997; Walls \& Paquin 2015; Wolf et al. 2007):

- the creation of the opportunities for EIP's development, in particular, through the establishment of standards for the resources exchange, the regulation of resource ownership and pricing policies, the simplification of environmental regulatory requirements and permitting procedures in the field of waste management;

- the stimulating of the development through the creation of tax incentives and subsidies allotment, the formation of special funds for financing the development of the EIP;

- the coordination of the network structures functioning through the implementation of intermediary functions for the information exchange, which will facilitate the reduction of transaction costs.

It is clear that the formation of institutional drivers for the development of the EIP should be based on the perception of the drivers of the industrial symbiosis models development. Particularly, the existing inter-firm relations including formed in the process of conquering new market opportunities, supply, and product distribution networks (Chertow \& Ehrenfeld 2012) are seen as the preconditions and basis for the formation of industrial symbiosis models (Baas \& Boons 2004). As Desroches (2002) and Ehrenfeld \& Gertler (1997) highlight, the models of industrial symbiosis appear as the result of business-to-business agreements fed on the economic interests primarily (for example, seeking the ways to reduce waste management costs, to get access to the cheaper resources, and to obtain the additional income) (Desroches 2002; Ehrenfeld \& Gertler 1997). It is emphasized that environmental benefits are of secondary importance, being valued, to a greater extent, in terms of gaining consumer loyalty and trust of the institutions (Desroches 2002). Therefore, the policy must focus on creating the right economic context for the development of industrial symbiosis models and the formation of an EIP first and foremost.

The forming-up of the inter-firm relationships essentially depends on the level of transaction costs. In the exchange of by-products and wastes process, such costs include the exploratory, regulatory, contractual and control costs (Chertow \& Ehrenfeld 2012; Ehrenfeld \& Gertler 1997). These costs reflect the "economic" dimension of material and energy flows as objects of the industrial symbiosis. This means that for the private agents the material and energy flows are primarily measured within the categories of transaction costs, transportation costs, cost of resources and their disposal. The level of these costs, compared with the potential revenues is the basis for the implementing of strategies that substantially comply with the concept of industrial ecology (i.e. models of industrial symbiosis). Ultimately, this will ensure the development of eco-industrial parks. The transaction costs minimization is also important in terms of interregional security, since their minimal levels 


\section{The International Journal}

ENTREPRENEURSHIP AND SUSTAINABILITY ISSUES

ISSN 2345-0282 (online) http://jssidoi.org/jesi/

2018 Volume 6 Number 1 (September)

http://doi.org/10.9770/jesi.2018.6.1(20)

would guaranty economic, social and environmental convergence (Melnyk \& Kubatko 2016). From these positions, it is obvious that the space of alternatives, formed by the institutional environment, should be based on the systemic and complex studies of flow processes in the light of the whole set of their measurements: ecological, social and economic as well. This will enable us to resolve the existing contradictions between the public (in this case, environmental) and private (economic) goals. However, the point to be emphasized is that understanding of the economic actors' decisions and their determinants is one of the main challenges for the industrial ecology (Baccini \& Brunner 2012; Kronenberg 2006) as the set of its tools and methods is insufficient to address it completely. For example, the LCA captures only the substance and form of the product related environmental impact. It does not make it possible to identify the factors (economic) of its minimization. The analysis of the composition and structure of energy and material flows (i.e. MFA) is not enough to make a decision on how to promote the integration as well as the formation and development of a local industrial ecosystem (Wolf et al. 2007, p. 454). In this context, the field for the application of the logistics methodology as a scientific discipline associated with material and energy flows researched in their economic essence is coming into being.

\section{The fundamentals of logistics}

The modern logistics as an interdisciplinary science (Delfmann et al. 2010; Klaus 2009; Kovács \& Spens 2005; Malindžák 2014; Møller 1995) comes from many scientific traditions and shaped by the influence of the economic and behavioral approaches (Arlbjørn \& Halldorsson 2002). The logistics concept originates mainly from the marketing, management, engineering (Kovács \& Spens 2005), business administration, economics, computer and social sciences (Delfmann et al., 2010), microeconomics and organization theory disciplines (Møller 1995). In a broad sense, the logistics appears as a "flow management philosophy" (Malindžák 2014, p. 47), the science about complex flows in networks, focused on the design, dynamics and management of these structures, that contributes to the growth and retention of "The Wealth of Nations" (Delfmann et al. 2010). More specifically, logistics is a branch of science related to managing, guaranteeing, and implementation of flows in chains and networks for the purpose of their global optimization (Malindžák 2014, p. 47). The methodology of logistics is aimed to model economic systems as networks, analyze their relationships thus to form the information basis for their optimal design (Møller 1995) and development in order to ensure progress in the balanced achievement of economic, environmental and social goals (Delfmann et al. 2010).

The flow thinking is the central element and a distinctive feature that defines the essence of the logistics as a discipline (Delfmann et al. 2010; Malindžák 2014; Arlbjørn \& Halldorsson 2002). This means that economic processes are considered as the flows of objects (Delfmann et al. 2010) that are studied from the technical, organizational and social points of view. The logistics is based on a systemic approach (Delfmann et al. 2010; Karatas-Cetin \& Denktas-Sakar 2013; Klaus 2009; Malindžák 2014; Nilsson \& Gammelgaard 2012; Novack et al. 1992; Arlbjørn \& Halldorsson 2002) and its scientific toolkit provides the space and time coordination of processes (Delfmann et al. 2010; Malindžák 2014) being focused on the inter-organizational interactions (Møller 1995) as well as on the issues of flows mobilization and control while studying the optimal configuration and organization of economic networks models (Delfmann et al. 2010). One should emphasize that the economic approach as one of the mainstays of the logistic concept focuses on full costs minimization (or profit maximization) (Karatas-Cetin \& Denktas-Sakar 2013; Arlbjørn \& Halldorsson 2002) as a criterion for such optimization modeling. The logistic flows are understood as a controlled movement of objects between cooperative elements (machines, activities, people, workplaces, etc.) linking them in chains and networks (Malindžák 2014, p. 49). The flow composition depends upon the objects (materials and substances) forming it as well as the context. The elements, as a rule, include the material objects such as raw materials, work in progress, finished products, goods as well as information and services flows (Klaus 2009; Arlbjørn \& Halldorsson 2002). At the same time, the composition of the flow elements can vary depending on the context in which they are 
The International Journal
ENTREPRENEURSHIP AND SUSTAINABILITY ISSUES

ISSN 2345-0282 (online) http://jssidoi.org/jesi/

2018 Volume 6 Number 1 (September)

http://doi.org/10.9770/jesi.2018.6.1(20)

investigated (i.e. level of analysis and purpose) (Arlbjørn \& Halldorsson 2002, p.25). This allows to cover the waste streams, gas-energy emissions and wastewater, services (including ecosystem), in particular, in view of the environmental objectives of logistics system analysis (Mishenin et al. 2015; Linton et al. 2007; Sarkis 2012), as well as people, services, finance, information and knowledge (Delfmann et al. 2010; Klaus 2009; Malindžák 2014; Sarkis 2012) in the studying of the logistics systems in socially important sectors: healthcare, education, etc. (Delfmann et al. 2010; Klaus 2009; Kubatko \& Kubatko 2016).

At the same time, the material flow is the main object in logistics considered as a system-forming, integrating a variety of activities factor, that broadly speaking, covers the full product lifecycle: from developing an idea to the final disposal of waste of consumption. The material flow simultaneously reflects the horizontal - the functional dimension of the logistics system, i.e. supply, production, distribution, service, etc. (Møller 1995). The basic tools and methods in the logistics are simulation and modeling. The most often used include the models of logistic flows, plans scheduling, decision making, optimization etc. (Malindžák 2014). The modeling of system dynamics also is used to study the relationships, organization and integrated development of logistic structures (Angerhofer \& Angelides 2000). It should be stressed that the life cycle analysis (Life Cycle Cost Analysis (LCCA), is also one of the main methods of the design of logistics system used to analyze costs (Dea \& Freeman 1995). The above analysis shows that the logistics forms the scientific and methodological basis for the modeling of an efficient system in terms of full costs, while also providing an optimal set of products and services that meet the needs of the consumer.

\section{The use of the industrial ecology and logistics methodologies to build the region's sustainable development policy}

In view of the aforesaid, the question arises about the possibility to form an integrated, complex "conceptual" space for the development of the policy of region's sustainable development based both on the industrial ecology and the logistics as flow sciences. To investigate the interconnection of these disciplines we are going through the generalization and comparison of their basic provisions (Table 1).

Table 1. The comparative analysis of the fundamentals of industrial ecology and logistics as sciences

\begin{tabular}{|l|l|l|}
\hline \multicolumn{1}{|c|}{ Criterion } & \multicolumn{1}{|c|}{ Industrial Ecology } & \multicolumn{1}{|c|}{ Logistics } \\
\hline Object of investigation & $\begin{array}{l}\text { The material and energy flows in } \\
\text { industrial systems (networks) }\end{array}$ & $\begin{array}{l}\text { The material, energy, information, } \\
\text { service, finance, people and knowledge } \\
\text { flows in economic systems (networks) }\end{array}$ \\
\hline Problem scope of research & $\begin{array}{l}\text { The inter-organizational relationships, } \\
\text { coordination }\end{array}$ & $\begin{array}{l}\text { The inter-organizational relationships, } \\
\text { coordination }\end{array}$ \\
\hline Focus of the research & Environmental impact & Full costs size \\
\hline Methodology & $\begin{array}{l}\text { Systemic approach } \\
\text { Theory of complexity }\end{array}$ & $\begin{array}{l}\text { Systemic approach } \\
\text { Theory of complexity }\end{array}$ \\
\hline Goal & $\begin{array}{l}\text { System optimization from the } \\
\text { environmental impact point of view }\end{array}$ & $\begin{array}{l}\text { System optimization from the full cost } \\
\text { minimization point of view }\end{array}$ \\
\hline Methods and tools & $\begin{array}{l}\text { LCA (environmental impact), analysis } \\
\text { (models) of material (substances) flows }\end{array}$ & $\begin{array}{l}\text { LCA (cost analysis), flow models, } \\
\text { optimization methods }\end{array}$ \\
\hline Organizational forms & Product (supply) chain, regional system & Enterprise, supply chain, regional system \\
\hline System types & Complex, adaptive, self-organized & Complex, adaptive, self-organized \\
\hline Modeling approaches & $\begin{array}{l}\text { Flow approach } \\
\text { Behavioral approach } \\
\text { Process approach } \\
\text { Actors approach }\end{array}$ & $\begin{array}{l}\text { Flow approach } \\
\text { Behavioral approach } \\
\text { Process approach } \\
\text { Economic approach }\end{array}$ \\
\hline Discipline's type & Normative, applied & Explanatory, applied \\
\hline
\end{tabular}

Source: authors' generalization 
The outlined above (table 1) suggests that industrial ecology and logistics are scientific disciplines that simultaneously examine various aspects (environmental impact and costs) of the industrial networks functioning through the emphasizing of the flow form of organization of the movement of resources (materials) and energy in these systems. The conceptual model for the mapping the relationship between these two disciplines is depicted in Fig. 1

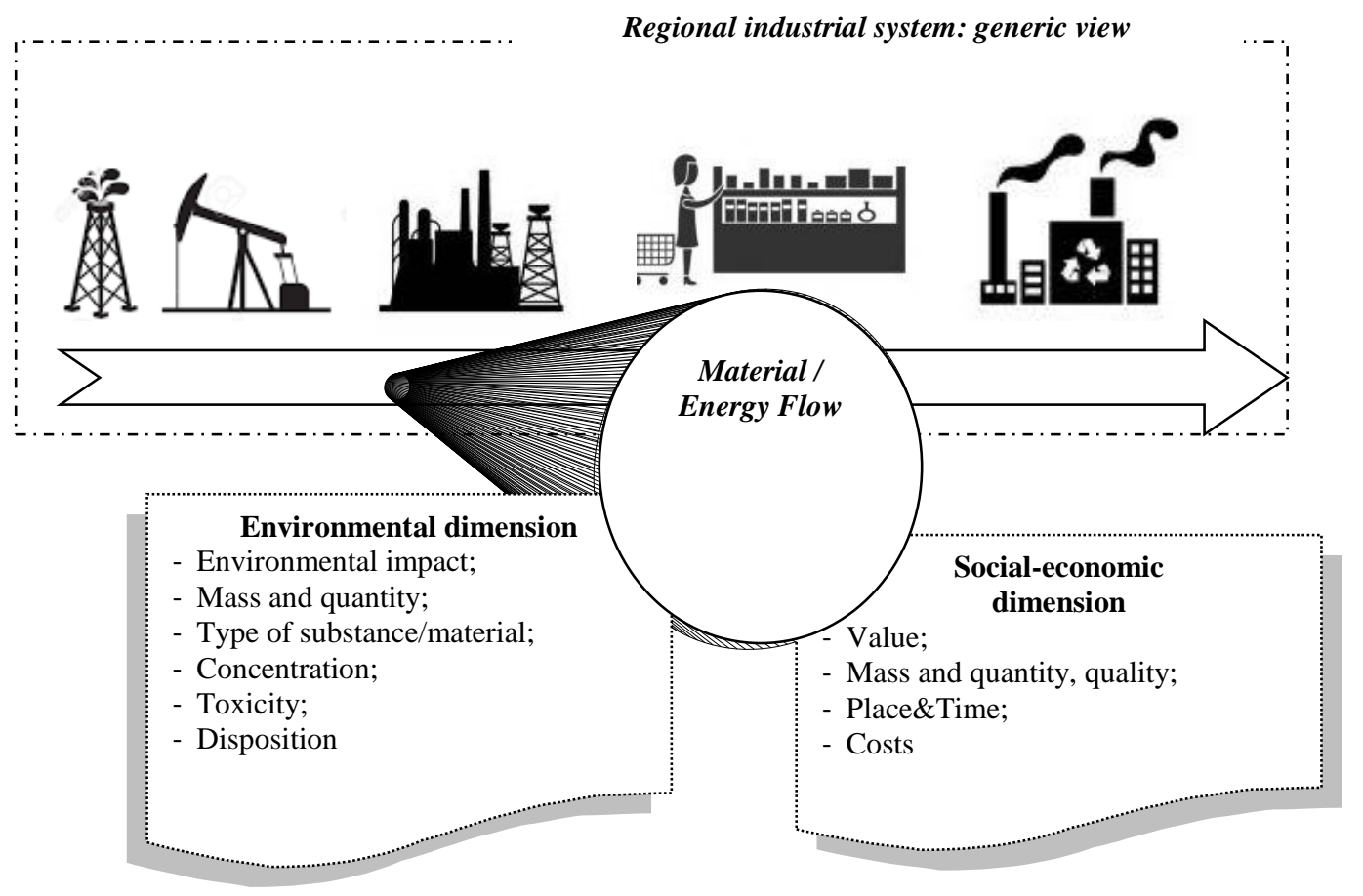

Fig.1. The multidimensional view of material/energy flow in the regional industrial system

Source: authors' development

Thus, the Fig. 1 illustrates that the material and energy flow in the regional system is a multidimensional thing. It exists in biophysical terms and hence has the "environmental" characteristics determined by the mass and quantity, type of substance, the degree of concentration, toxicity, and place of disposal. At the same time, it is valuable from the standpoint of the role in the socio-economic system and is measured by the consumer's value, costs of resources, transport costs, costs of management (disposition), etc. The logistics, considering the "socioeconomic" dimension of flow processes and their system-wide economic optimization, can thus serve as a methodological basis for the formulation and implementation of policy aimed to achieve a set of region's sustainable development goals such as: the economic development (through the minimization of resource flow costs that leads to the improvement of the competitiveness of goods and services produced regionally), the social welfare and wealth of the population (through the provision of the supply of goods and services of the required quality with a minimum level of costs in accordance with the needs of consumers completely and in time), as well as the environmental goals through the minimization of the environmental impact of optimized production and consumption flow processes in the region. 
The International Journal

ENTREPRENEURSHIP AND SUSTAINABILITY ISSUES

ISSN 2345-0282 (online) http://jssidoi.org/jesi/

2018 Volume 6 Number 1 (September)

http://doi.org/10.9770/jesi.2018.6.1(20)

The implementation of the logistics approach when managing the regional development requires considering all processes and components that constitute the region's economy as the elements of a regional logistic system. These typical elements include the spheres of production, supply, distribution, consumption, and disposal, integrated into a single flow of resources movement from the primary source (extraction of natural resources) to the production and consumption wastes disposal, and reflect the functional areas of logistics management in the region. Full cost analysis should be complemented by the environmental assessment of all stages of the resource flow movement. The latter requires taking into account the "environmental" dimension of material and energy flows in the process of the design and management of a regional logistics system. This needs the transformation of the "environmental" meaning of the material and energy flows into the corresponding social-economic value on the basis of a more complete, more realistic assessment of the natural goods (resources and conditions) from the point of view of their public value (for example, the providing, supporting, restorative functions) and will allow to consider waste and by-products as the full-fledged components of material and energy flows in the system of commodity movement, i.e. social-economic system. The systemic projection of the full, environmentally-adjusted social costs should be seen as a part of the search for solutions for the development of eco-industrial parks in a form of a regional logistic system (Dea \& Freeman 1995; Quariguasi et al. 2008). The goal here is to optimize the flows within the regional eco-industrial logistic system based on the minimization of the overall social costs associated with the movement and transformation of resources and energy in industrial networks.

In this context, it is possible to propose the following stages of region's policy formation:

1) The identification of the flows in the regional economic system and their analysis with the simultaneous study of the environmental impact at each stage of the resource flow (resource exhaustion, waste and emissions generation, wastewater discharge, emission of pollutants in gaseous forms etc.), thus forming the green economic flows;

2) The analysis and assessment of the public value of natural goods (including ecosystem services as well), taking into account the degree of their scarcity in the region and alternatives of using;

3) The estimation of social costs, associated with resource flows in the region;

4) The optimization of economic flows on the criterion of the full social costs minimization;

5) The formation of the methods and tools of integrated environmental-economic policy and management, which should ensure the optimal state of green economic flows and by that provide the achievement of the environmental goals of the regional industrial system.

The authorities can thus act as a leader in the process of an inefficient regional logistics system restructuring through:

- The strategic planning of the region's development on the basis of a system of socio-ecological and economic indicators (in particular, based on the full social costs, that take into account environmentally related variables);

- The use of the system of economic levers (for example, the pricing and the taxation) based on the proper valuation of natural resources and conditions;

- The administrative regulation of economic activities, including those in the field of natural resources management (for example, the introduction of the system of permits for special use of resources);

- The balanced stimulation of investments and innovative activities;

- The participation of the public sector in the creation of the necessary infrastructure for the collection, reuse, and recycling of wastes, further use of wastes and secondary raw materials (by-products), as well as an implementation of the informational support of these processes;

- The development of public procurement programs for the products made from the secondary and recycled materials for the needs of the community. 
The International Journal

ENTREPRENEURSHIP AND SUSTAINABILITY ISSUES

ISSN 2345-0282 (online) http://jssidoi.org/jesi/

2018 Volume 6 Number 1 (September)

http://doi.org/10.9770/jesi.2018.6.1(20)

In our view, the use of the logistics methodology combined with the industrial ecology principles to manage ecological-economic relations at the regional level will allow solving the key tasks of regional governing on the innovative bases. Among others, these tasks include: the development of an optimal strategy in the regulation of structural proportions and material flows of public production and consumption in the regional scale; the selection of efficient economic and administrative tools for the optimization of material and related flows of services, finances and information which in turn will contribute to the reducing of the environmental impact throughout the region.

\section{Conclusions}

Environmentally targeted regulation of material and energy flows in the regional space that embodies the philosophy of industrial ecology should be considered in the light of the need to ensure the population welfare and from the viewpoint of the economic interests of business agents. Considering logistics as a science of managing the complex flows in networks allows not only to provide the economically high-efficient movement of resources in the socio-economic system, but also to consider the logistics and the industrial ecology arow as the parts of the scientific base aimed to achieve the goals of sustainable development of industrial systems on different hierarchical levels. These two disciplines should be seen as complementary and those that receive a newly integrated vector of development under the conditions of sustainable development paradigm. Within the given context the in-depth insight of the object of management is important. It is the material flow, investigated both in the industrial ecology and logistics, but from different perspectives: the physical and environmental in the view of the industrial ecology and the physical and socio-economic within the framework of the logistics. The integration of these two aspects and thus disciplines' fundamentals should, in our view, serve as a methodological framework for the justification of conditions to be created by the institutional environment for the implementation of policy and mechanisms for the development of regions on a new, sustainable basis.

In the light of this, one should emphasize the need for the ecologically caused improvement of logistics knowledge. This should include, in particular: the methodological basis improvement taking into account the foundations of the ecological economics, environmental ethics, principles of industrial ecology, etc., the goals reframe (i.e. logistics management should be regarded as aimed at achieving a complex of socio-ecological and economic objectives of resource movement and use), the broaden interpretation of the object of logistic management including the waste streams, returned goods, by-products, emissions as well as related information, finances and services, the development of methodical basis for the decision-making through the use of material flows analysis and environmental life cycle assessment tools.

Thus, the integration of the conceptual provisions of logistics and industrial ecology in the context of sustainable development allow to view the eco-industrial parks as the regional logistic systems with the optimal flows structure, where the total social costs associated with the flow of goods (and, accordingly, the natural material and energy resources involved in the process of creating value, expressed in commodity form) are minimized and the environmental impact consequently too. Therefore, there is an obvious need for the further researches concerning approaches to the modeling of complex flows at the regional level taking into account physical, social, economic and environmental variables and their valuations, the methodical tools for evaluating and analyzing the full social costs associated with the resource flow in the regional system, as well as the models and algorithms for making managerial decisions in the public sector. 


\section{References}

Angerhofer, B. J.; Angelides, M. C. 2000. System dynamics modelling in supply chain management: research review. The 2000 Winter Simulation Conference: Proceedings, Vol.1. Ed. by Joines, J. A.; Barton, R. R.; Kang, K.; Fishwick, P. A. December 10-13. Orlando, FL, U.S.A, 342-351. DOI: 10.1109/WSC.2000.899737

Arlbjørn Stentoft, J.; Halldorsson, A. 2002. Logistics knowledge creation: reflections on content, context and processes, International Journal of Physical Distribution \& Logistics Management 32(1): 22-40. DOI: https://doi.org/10.1108/09600030210415289

Ashton, W. S. 2009. The structure, function, and evolution of a regional industrial ecosystem, Journal of Industrial Ecology 13(2): 228246. DOI: https://doi.org/10.1111/j.1530-9290.2009.00111.x

Baas, L. W.; Boons, F. A. 2004. An industrial ecology project in practice: Exploring the boundaries of decision-making levels in regional industrial systems, Journal of Cleaner Production 12(8-10): 1073-1085. DOI: https://doi.org/10.1016/j.jclepro.2004.02.005

Baccini, P.; Brunner, P. H. 2012. Metabolism of the Anthroposphere: Analysis, Evaluation, Design. 2nd ed. London: The MIT Press. Access mode: https://mitpress.mit.edu/books/metabolism-anthroposphere-second-edition

Boons, F. A.; Baas, L. W. 1997. Types of industrial ecology: The problem of coordination, Journal of Cleaner Production 5(1-2): 79-86. DOI: https://doi.org/10.1016/S0959-6526(97)00007-3

Chertow, M.; Ehrenfeld, J. 2012. Organizing Self-Organizing Systems: Toward a Theory of Industrial Symbiosis, Journal of Industrial Ecology 16(1): 13-27. DOI: https://doi.org/10.1111/j.1530-9290.2011.00450.x

Constanza, R.; Daly, H.; Bartholomew, J. 1991. Goals, agenda and policy recommendations for ecological economics. Available on the Internet: http://www.uvm.edu/ jfarley/EEseminar/readings/Costanza,\%20Daly,\%20Barth\%201991.pdf

Dea, K. O.; Freeman, G. 1995. Environmental Logistics Engineering: A New Approach to Industrial Ecology. Total Quality Environmental Management 4 (Summer): 73-86. DOI: https://doi.org/10.1002/tqem.3310040409

Delfmann, W.; Dangelmaier, W.; Günthner, W.; Klaus, P.; Overmeyer, L.; Rothengatter, W.; Weber, J.; Zentes, J. 2010. Towards a science of logistics: Cornerstones of a framework of understanding of logistics as an academic discipline, Logistics Research 2(2): 57-63. DOI: https://doi.org/10.1007/s12159-010-0034-5

Desroches, P. 2002. Eco-Industrial Parks: The Case for Private Planning, The Independent Review 33(5): 345-371. Access mode: http://www.independent.org/pdf/tir/tir_05_3_desrochers.pdf

Ehrenfeld, J. R. 2000. Industrial Ecology: Paradigm Shift or Normal Science?, American Behavioral Scientist 44(2): 229-244. DOI: https://doi.org/10.1177/0002764200044002006

Ehrenfeld, J.; Gertler, N. 1997. Industrial Ecology in Practice, Journal of Industrial Ecology 1(1): 67-79. DOI: https://doi.org/10.1162/jiec.1997.1.1.67

Hernández-Hernández, H. J.; Montoya Torres, J. R. 2011. From Sustainable Supply Chains to Closed-Loop Systems: A Critical Overview of Scientific Literature. Available on the https://www.researchgate.net/publication/265184971_From_Sustainable_Supply_Chains_to_Closed-

Loop Systems A Critical Overview of Scientific Literature

Hond F. D. 2000. Industrial ecology: a review, Regional Environmental Change 1(2):60-69. Access mode: https://pdfs.semanticscholar.org/5a53/6dea8112c1a8e15c82bd42880d9ea3c037fb.pdf

Kan C. W. 2007. Environmental Supply Chain Management for Textile and Apparel Sector, Research Journal of Textile and Apparel 11 (1): 57-70. http://hdl.handle.net/10397/7874

Karatas-Cetin, C.; Denktas-Sakar, G. 2013. Logistics research beyond 2000: Theory, method and relevance, Asian Journal of Shipping and Logistics 29(2): 125-144. DOI: https://doi.org/10.1016/j.ajsl.2013.08.001 
Klaus, P. 2009. Logistics research: a 50 years' march of ideas, Logistics Research 1(1): 53-65. DOI: https://doi.org/10.1007/s12159-008$\underline{0009-y}$

Korhonen, J. 2002. Two Paths to Industrial Ecology: Applying the Product-based and Geographical Approaches, Journal of Environmental Planning and Management 45(1): 39-57. DOI: https://doi.org/10.1080/09640560120100187

Korhonen, J.; Honkasalo, A.; Seppälä, J. 2018. Circular Economy: The Concept and its Limitations, Ecological Economics 143: 37-46. DOI: https://doi.org/10.1016/j.ecolecon.2017.06.041

Kovács, G. 2017. Circular economy vs. closed loop supply chains: what is new under the sun?, in Moula, Munjur E.; Sorvari, J.; Oinas, P. (Eds.). Constructing a Green Circular Society. Helsinki: Unigrafia Oy, 6-13. https://helda.helsinki.fi/bitstream/handle/10138/231630/ebook2017\%28pdf\%29.pdf?sequence=1

Kovács, G.; Spens, K. M. 2005. Abductive reasoning in logistics research, International Journal of Physical Distribution \& Logistics Management 35(2): 132-144. DOI: https://doi.org/10.1108/09600030510590318

Kronenberg, J. 2006. Industrial ecology and ecological economics. Progress in Industrial Ecology 3(1/2): 95-113. DOI: https://doi.org/10.1504/PIE.2006.010043

Kubatko, O.; Kubatko, O. 2017. Economic Estimations of Pollution Related Cancer and Nerves Morbidity, International Journal of Ecology \& Development, 32 (1); 33-43. Access mode: http://www.ceser.in/ceserp/index.php/ijed/article/view/4765

Leigh, M.; Li, X. 2015. Industrial ecology, industrial symbiosis and supply chain environmental sustainability: a case study of a large UK distributor, Journal of Cleaner Production 106: 632-643. DOI: https://doi.org/10.1016/j.jclepro.2014.09.022

Linton, J. D.; Klassen, R.; Jayaraman, V. 2007. Sustainable supply chains: An introduction, Journal of Operations Management 25(6): 1075-1082. DOI: https://doi.org/10.1016/j.jom.2007.01.012

Malindžák, D. 2014. The Basic Principle of Logistic Theory, Applied Mechanics and Materials 708: 47-52. DOI: https://doi.org/10.4028/www.scientific.net/AMM.708.47

Melnyk, L.; Kubatko O. 2012. Economic valuation of environmental goods and services in Ukraine, Actual Problems of Economics, 138(12): 106-112. Access mode: https://www.researchgate.net/publication/298454313_Economic_valuation_of_environmental_goods_and_services_in_Ukraine

Melnyk L.; Kubatko O. 2013. The EU experience for economic systems adaptation to resource fluctuations through green industries innovations, Actual Problems of Economics, 150(12): 36-42. Access mode: https://eco-science.net/downloads/

Melnyk, L.; Kubatko O. 2016. Were Ukrainian regions too different to start interregional confrontation: Economic, social and ecological convergence aspects? Economic Research-Ekonomska Istrazivanja, 29 (1); 573-582. https://doi.org/10.1080/1331677X.2016.1174387

Møller, C 1995, Logistics Concept Development - Towards a Theory for Designing Effective Systems. PhD thesis. Aalborg Universitetsforlag. Access mode: http://www.forskningsdatabasen.dk/en/catalog/2389389805

Nilsson, F.; Gammelgaard, B. 2012. Moving beyond the systems approach in SCM and logistics research, International Journal of Physical Distribution \& Logistics Management 42(8/9): 764-783. DOI: https://doi.org/10.1108/09600031211269749

Novack, R. A.; Rinehart, L. M.; Wells, M. V. 1992. Rethinking Concept Foundations in Logistics Management, Journal of Business Logistics 13(2). Available on the Internet: https://search.proquest.com/openview/85be26a6665a96268574d5a31675560a/1?pqorigsite $=$ gscholar \&cbl $=36584$

Quariguasi Frota Neto, J.; Bloemhof-Ruwaard, J. M.; van Nunen, J. A. E. E.; van Heck, E. 2008. Designing and evaluating sustainable logistics networks, International Journal of Production Economics 111(2): 195-208. DOI: https://doi.org/10.1016/j.ijpe.2006.10.014

Sarkis, J. 2012. A boundaries and flows perspective of green supply chain management, Supply Chain Management: An International Journal 17(2): 202-216. DOI: https://doi.org/10.1108/13598541211212924 
The International Journal

ENTREPRENEURSHIP AND SUSTAINABILITY ISSUES

ISSN 2345-0282 (online) http://jssidoi.org/jesi/

2018 Volume 6 Number 1 (September)

http://doi.org/10.9770/jesi.2018.6.1(20)

Schiller, F.; Penn, A. S.; Basson, L. 2014. Analyzing networks in industrial ecology - A review of Social-Material Network Analyses, Journal of Cleaner Production 76: 1-11. DOI: https://doi.org/10.1016/j.jclepro.2014.03.029

Seuring, S. 2004. Industrial Ecology, Life Cycles, Supply Chains: Interrelations, Business Strategy and the Environment 13: 306-319. DOI: https://doi.org/10.1002/bse.418

Sineviciene L.; Sotnyk I.; Kubatko O. 2017. Determinants of energy efficiency and energy consumption of Eastern Europe post-communist economies, Energy \& Environment, 28(8): 870-884. https://doi.org/10.1177/0958305X17734386

Walls, J. L.; Paquin, R. L. 2015. Organizational Perspectives of Industrial Symbiosis: A Review and Synthesis, Organization and Environment 28(1): 32-53. DOI: https://doi.org/10.1177/1086026615575333

Wichaisri, S.; Sopadang, A. 2017. Integrating sustainable development, lean, and logistics concepts into a lean sustainable logistics model, International Journal of Logistics Systems and Management 26(1): 85-104. DOI: https://doi.org/10.1504/IJLSM.2017.080631

Wolf, A.; Eklund, M.; Söderström, M. 2007. Developing integration in a local industrial ecosystem - an explorative approach, Business Strategy and the Environment 16(6): 442-445. DOI: https://doi.org/10.1002/bse.485

Zhu, Q.; Sarkis, J.; Lai, K. 2008. Green supply chain management implications for "closing the loop", Transportation Research, Part E: Logistics and Transportation Review 44(1): 1-18. DOI: https://doi.org/10.1016/j.tre.2006.06.003

Мишенин Е.В.; Коблянская И.И. 2017. Перспективы и механизмы развития «циркулярной» экономики в глобальной среде [Mishenin, Ye. V.; Koblianska, I.I. 2017. Perspectives and mechanisms of "circular" economy global development], Маркетинг $i$ менеджмент інноваџій [Marketing and Management of Innovations] 2: 329-343. DOI: https://doi.org/10.21272/mmi.2017.2-31

Мішенін, Є. В.; Коблянська, I.I.; Мішеніна, Н.В. 2015. Стратегія реалізації екологоорієнтованого логістичного управління виробничою системою підприємства [Mishenin, Ye. V.; Koblianska, I.I.; Mishenina, N.V. 2015. Strategy of implementation of ecologically-oriented logistical management of enterprise production system], Економічний часопис - XXI [Economic Annals-XXI] 3-4 (1): 64-67. - Access mode: http://nbuv.gov.ua/UJRN/ecchado_2015_3-4\%281\%29_16 
Yevhen MISHENIN

ORCID ID: orcid.org/0000-0003-1597-3270

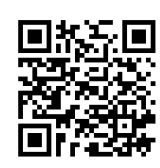

Inna KOBLIANSKA

ORCID ID: orcid.org/0000-0002-7844-9786

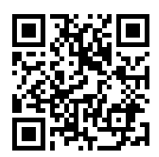

\section{Viktoriya MEDVED}

ORCID ID: orcid.org/0000-0002-2257-6276

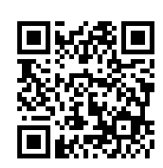

\section{Yuliia MAISTRENKO}

ORCID ID: orcid.org/0000-0003-1291-016X

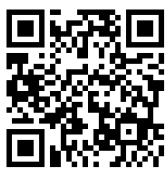

Copyright (C) 2018 by author(s) and VsI Entrepreneurship and Sustainability Center

This work is licensed under the Creative Commons Attribution International License (CC BY).

http://creativecommons.org/licenses/by/4.0/

\section{(c) (7) Open Access}

